\title{
Health Risk Assessment of Heavy Metals and Microbial Quality of Local Tomato (Solanum lycopersicum) of Ouagadougou, Burkina Faso
}

\author{
Marius Kounbèsiounè Somda ${ }^{1,2}$, Donatien Kabore ${ }^{3}$, Iliassou Mogmenga ${ }^{1}$, Cheik A. T. Ouattara ${ }^{2}$, \\ Assietta Ouattara', Yerobessor Dabire1, Mahamadi Nikiema1, Henriette B. Mihin'2, \\ Agbémébia Yawovi Akakpo², Ousséni Ouedraogo ${ }^{4}$, Alfred S. Traore ${ }^{1,2}$, Aboubakar S. Ouattara ${ }^{1}$ \\ ${ }^{1}$ Laboratory of Microbiology and Microbial Biotechnology, Research Center in Biological Food and Nutrition Sciences (CRSBAN), \\ Department of Biochemistry and Microbiology, University Ouaga1 Pr Joseph KI-ZERBO, Ouagadougou, Burkina Faso \\ ${ }^{2}$ Laboratory of Food Technology, Department of Biochemistry and Microbiology, University Ouaga1 Pr Joseph KI-ZERBO, \\ Ouagadougou, Burkina Faso \\ ${ }^{3}$ Department of Food Technology, National Center of Scientific and Technological Research, Ouagadougou, Burkina Faso \\ ${ }^{4}$ Agriculture Ministry and Hydraulic Developments, Multipurpose Agricultural Center of Matourkou, Bobo-Dioulasso, Burkina \\ Faso \\ Email: *sokmarius@gmail.com
}

How to cite this paper: Somda, M.K., Kabore, D., Mogmenga, I.., Ouattara, C.A.T., Ouattara, A., Dabire, Y., Nikiema, M., Mihin, H.B., Akakpo, A.Y., Ouedraogo, O., Traore, A.S. and Ouattara, A.S. (2019) Health Risk Assessment of Heavy Metals and Microbial Quality of Local Tomato (Solanum lycopersicum) of Ouagadougou, Burkina Faso. Journal of Environmental Protection, 10, 942-957.

https://doi.org/10.4236/jep.2019.107056

Received: May 28, 2019

Accepted: July 28, 2019

Published: July 31, 2019

Copyright (c) 2019 by author(s) and Scientific Research Publishing Inc. This work is licensed under the Creative Commons Attribution International License (CC BY 4.0).

http://creativecommons.org/licenses/by/4.0/

(c) (i) Open Access

\begin{abstract}
Tomato fruit enormously consumed in Burkina Faso is a source of health risk due to its quality. The plant of tomato cultivated in most the industrially polluted area as Ouagadougou, accumulates significant quantities of heavy metals and microorganisms and could be dangerous for consumption. The present study was conducted to investigate heavy metal and microbial contamination in soils wastewater and vegetables (tomato fruit) and to evaluate the possible health risks associated with the consumption of vegetables. Total concentrations of $\mathrm{As}, \mathrm{Cd}, \mathrm{Cr}, \mathrm{Cu}, \mathrm{Hg}, \mathrm{Ni}$, Se and $\mathrm{Zn}$ were determined using atomic absorption spectrophotometry. Transfer factor (TF), daily intake of metals (DIM) and health risk index (HRI) were also calculated. Microbial quality was analyzed for the presence of foodborne pathogens. The $\mathrm{pH}$ involved from $6.50 \pm 0.1$ to $9.40 \pm 0.12$ respectively for Boulmiougou and Kossodo. The mean metal concentrations indicated that soils were strongly polluted followed by wastewater and vegetable. The range of the mean values (in $\mathrm{mg} \cdot \mathrm{kg}^{-1}$ ) exhibited by $\mathrm{As}, \mathrm{Cd}, \mathrm{Cr}, \mathrm{Cu}, \mathrm{Hg}, \mathrm{Ni}$, Se and $\mathrm{Zn}$ in tomato fruit was $17.80 \pm 0.32,2.71 \pm 0.02,11.57 \pm 0.2,203.41 \pm 1.20,15.13 \pm 0.30,53.18 \pm 0.20$, $38.56 \pm 0.10,109.13 \pm 0.25$ concerning samples of Boulmiougou and $3.47 \pm$ $0.15,2.78 \pm 0.01,22.11 \pm 0.1,242.85 \pm 2.10,14.86 \pm 0.10,132.19 \pm 1.50,33.23$ $\pm 0.15,146.43 \pm 1.12$ for Kossodo. Microbial count was below to acceptable limits for vegetable, but underlined the presence of spoiler and foodborne
\end{abstract}


pathogens. However, the daily intake of metals (DIM) and the health risk index (HRI) values were found to be under to the prescribed maximum tolerable.

\section{Keywords}

Heavy Metal, Microbial Quality, Tomato Fruit, DIM, HRI, Burkina Faso

\section{Introduction}

Solanaceae family member tomato is one of the world's most cultivated vegetables with a worldwide production of 129,650,000 tons [1]. In Burkina Faso, agriculture is the main source of income for the population and the mainstay of the country's food security. Tomato production comes second after onion bulb and generates significant foreign currency influx for the national economy. The national tomato production is 157,086 tons a year and remains the most profitable vegetable farming in the country with total sales valued at $117 €$ million [2]. Tomato fruits are usually eaten whole in salads, cooked in sauces, soup and meat, fish dishes or consumed as paste and catsup [3] [4]. It contains many nutrients, anti-oxidants and secondary metabolites such as vitamins $\mathrm{C}$ and $\mathrm{E}$, b-carotene, lycopene, flavonoids, organic acids, phenolics and chlorophyll, which are important for human health [4] [5]. But Agricultural soils and irrigation water in many parts of the world and Burkina are slightly to be contaminated by toxic heavy metals. This could be due to industrial wastewater, sewage sludge applications, fertilizers, and watering practices in agricultural lands. The use of wastewater from the city in agriculture irrigation may have significant effects of accumulation of toxic heavy metals and microorganisms in soils and agricultural products [6] [7] [8] [9].

In Burkina popular street foods include ready-to-eat red tomato normally eaten with salads, cooked in sauces, soup and meat, fish dishes. Nevertheless, metals most often found as contaminants in vegetables as tomato can pose a significant health risk to humans, when they reach high concentrations in the body [10].

The uptake of dietary heavy metal among populations causes serious health problems including reduced immunological defenses, intrauterine growth retardation, impaired psychosocial behaviors, and disabilities associated with malnutrition and a high prevalence of upper gastrointestinal cancer [11].

Numerous literature suggests that foodborne illnesses of microbial and heavy metal origins such as diarrhoea have been recognized as the major source of hospital attendance in Burkina, Ghana whilst in Africa, $16 \%$ of deaths among children under five years are directly attributable to diarrhoeal diseases [12].

Pathogenic microorganisms present in ready-to-eat foods as tomato indicates a need for quality assurance improvements by local producers in order to reduce consumer risk of exposure to infectious foodborne agents [13]. 
According to Gibbons et al. [13] ensuring good quality raw materials, adequate lethality treatment, and effective sanitation of both the equipment and processing environment are crucial in preventing all forms of food contamination.

This study was carried out with the aim to assess the health risk associated with heavy metals intake and the microbial quality of tomato produced in two sites of Ouagadougou, Burkina Faso.

\section{Material and Methods}

\subsection{Study Area}

The study was conducted in Ouagadougou capital of Burkina Faso. Two main areas presented in Figure 1 as Boulmiougou and Kossodo were selected on the basis of groundwater and urban drains water irrigation. GPS Garmin eTrex Vista was used to registrate GPS coordinates of study sites at Ouagadougou. The site of Boulmiougou was located at $12^{\circ} 20^{\prime} 20^{\prime \prime}$ North latitude and $1^{\circ} 35^{\prime} 33^{\prime \prime}$ West longitude. The Kossodo site is on the north-eastern edge of the Bangr-Weogo forest. It covers a vast flood plain of one hundred hectares. It is located at $12^{\circ} 24^{\prime} 34^{\prime \prime}$ latitude North and $1^{\circ} 31^{\prime} 27^{\prime \prime}$ longitude West.

\subsection{Collection of Samples}

\section{Soil sampling}

Soil samples were taken from $0-30 \mathrm{~cm}$ depth in two sites (Boulmiougou and Kossodo) and prepared for physical and chemical analysis and heavy metal content using method of Somda et al. [9]. The temperature of study site was ranged from $24.6^{\circ} \mathrm{C}$ to $36.9^{\circ} \mathrm{C}$ and $24.5^{\circ} \mathrm{C}$ to $36.7^{\circ} \mathrm{C}$ respectively for Boulmiougou and Kossodo.

\section{Vegetable and wastewater sampling}

Tomato plants were grown very close to industries environment and affected by human activities. The harvesting was at the end of October, 2018. Samples
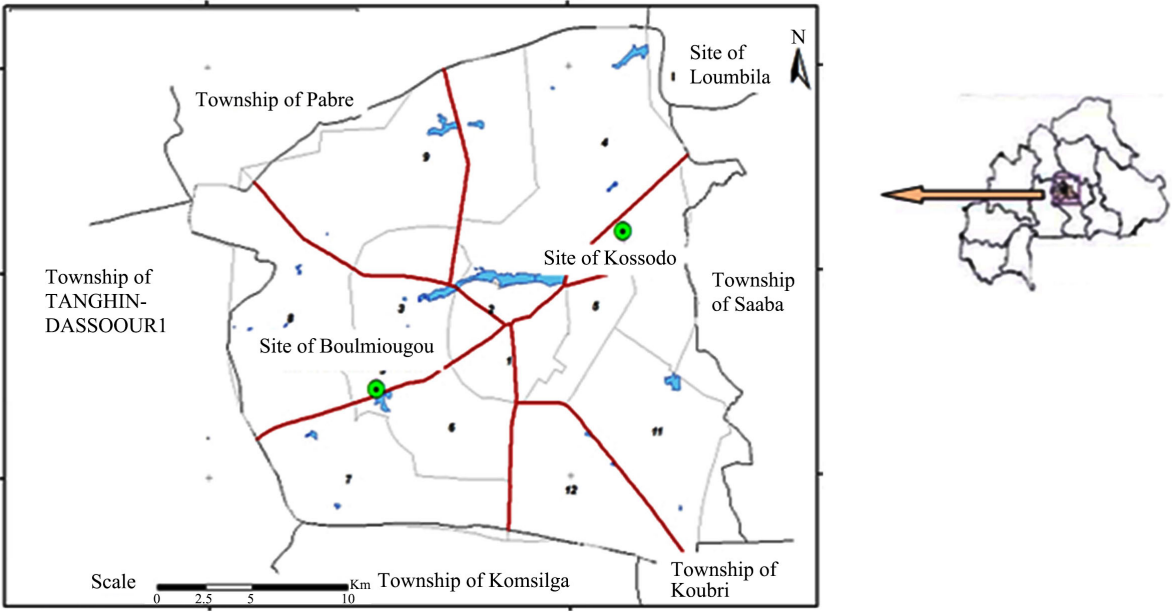

Figure 1. Localization of sites of samples collection at Ouagadougou. 
were taken by hands protected with vinyl gloves and carefully packed in polyethylene bags [14]. Fruit-sets of tomato were hand harvested, and low groundwater (wastewater) was collected from two sites (Boulmiougou and Kossodo) of production. The samples were processed according to the method of Somda et al. [9].

\section{Processing of samples}

The heavy metal concentration was determined in soil, wastewater and fruit-sets of tomato using the method of wet mineralization [15]. Fruit-sets of tomato were carefully washed with distilled water, dried at $105^{\circ} \mathrm{C}$ for $24 \mathrm{~h}$, powdered and weighted for analysis [16]. Together with fruit-sets harvesting for heavy metal analysis, soil and wastewater were taken from each one of the harvested plants for investigation on microorganisms.

\subsection{Wastewater Physico-Chemical Analysis}

The parameters analyzed have concerned: $\mathrm{pH}$, Conductivity (C), Suspended Solids (SS), Total Soluble Salts (TSS), Sodium Adsorption Ratio (SAR), Biochemical Oxygen Demand (BOD5), N- $\mathrm{NH}_{4}, \mathrm{~N}-\mathrm{NO}_{3}$, Phosphorus (P). Parameters were analyzed according to methods of American Public Health Association [17].

\subsection{Acid Digestion and Heavy Metals Analysis}

The digestion was made in autoclave using $100 \mathrm{ml}$ bottles. Tri-acid mixture (15 ml, $70 \%$ high purity $\mathrm{HNO}_{3}, 65 \% \mathrm{HClO}_{4}$ and $70 \% \mathrm{H}_{2} \mathrm{SO}_{4} ; 5: 1: 1$ ) was added to the beaker containing $1 \mathrm{~g}$ dry vegetable sample [18]. The mixture was then digested at $80^{\circ} \mathrm{C}$ till the transparent solution was achieved.

After cooling, the digested samples were filtered using Whatman No. 42 filter paper and the filtrate was diluted to $50 \mathrm{ml}$ with deionised water. Determination of the heavy metals such as, $\mathrm{As}, \mathrm{Cd}, \mathrm{Cr}, \mathrm{Cu}, \mathrm{Hg}, \mathrm{Ni}, \mathrm{Se}$ and $\mathrm{Zn}$ in the filtrate of samples and atmospheric deposits was achieved by atomic absorption spectrophotometer (Shimadzu Model 6800 with graphite furnace Model GFA 7000).

Thus wastewater parameters were analyzed according to the calibration methods used by the American Public Health Association for water and wastewater Analysis [17].

\subsection{Risk Assessment}

\section{Translocation factor calculation}

Transfer factor is the ratio of the concentration of heavy metals in a plant to the concentration of heavy metals in soil. The transfer factors $(T F)$ for each heavy metal was computed based on the method described by Li et al. [19], Balkhair and Ashraf [20]. The $T F$ value for the selected heavy metals was calculated according to the following equation:

$$
T F=\left[P_{s}\left(\mathrm{mg} \cdot \mathrm{kg}^{-1} \text { dry weight }\right)\right] /\left[S_{t}\left(\mathrm{mg} \cdot \mathrm{kg}^{-1} \text { dry weight }\right)\right]
$$


where:

$\boldsymbol{P}_{\boldsymbol{s}}$ : plant-metal content originating from the soil, $\boldsymbol{S}_{\boldsymbol{i}}$ the total heavy metal contents in the soil.

Daily intake of metals (DIM)

Daily intake of vegetables in adult was calculated by data obtained during the survey through a questionnaire. DIM was calculated by the following equation [21]:

$$
D I M=\left[C_{\text {metal }} \times C_{\text {factor }} \times D_{\text {foodintake }}\right] / B_{\text {average weight }}
$$

$C_{\text {metal }}:$ Heavy metal concentrations in plants $\left(\mathrm{mg} \cdot \mathrm{kg}^{-1}\right)$.

$C_{\text {factor: }}$ Conversion factor (CF) of 0.070 was used for the conversion of fresh vegetables to dry weight.

$D_{\text {food intake }}$ : Daily intake of the food crops was $0.50 \mathrm{~kg} \cdot$ person $^{-1} \mathrm{~d}^{-1}$.

$B_{\text {average weight }}$ Body weight for the adult population was $55.0 \mathrm{~kg}$.

These values were used for the calculation of HRI as well.

Health risk index (HRI)

The HRI refers to the ratio of the daily intake of metals in the food crops to the oral reference dose $(R f D)$ [22] and was calculated using the following equation: $H R I=D I M / R f D$.

An $H R I>1$ for any metal in food crops indicates that the consumer population faces a health risk.

\subsection{Microbiological Study}

Viable microorganisms of different samples were assessed, as: Total mesophilic aerobic [23], total coliform and fecal coliform [24], E. coli [24], Enterobacteriaceae [25], Salmonella spp. [26], Staphylococcus aureus [27]. On the other hand, numeration of fungi and detection Pseudomonas spp. were made [28]. The Principe of standard plate count was used for isolation and count of microorganism different groups. Microbial counts were expressed as the log of colony-forming-units per $\mathrm{ml}$ for liquid or per $\mathrm{g}$ for solid sample analyzed.

\subsection{Statistical Analysis}

Two-way analysis of variance (ANOVA) was used with STAT5 software version 8 to determine any significant difference at $5 \%$ probability of the studied metals and microorganisms in the various samples while Monte-Carlo simulation was used to estimate the dietary intake of the heavy metals by the populace.

\section{Results and Discussion}

\subsection{Wastewater Properties}

Physico-chemical parameters of wastewater of the investigated sites were significantly different $(\mathrm{P}<0.01)$ and means values were given in Table 1 . The $\mathrm{pH}$ of wastewater was ranged with significant difference from $6.50 \pm 0.10$ to $9.40 \pm 0.12$ respectively for Boulmiougou and Kossodo. Wastewater Kossodo was highly basic than dam water of Boulmiougou $(\mathrm{P}<0.01)$ at threshold of $5 \%$. Also it 
Table 1. Physico-chemical of irrigation wastewater.

\begin{tabular}{|c|c|c|c|}
\hline Parameters & Site of Boulmiougou & Site of Kossodo & FAO standards \\
\hline $\mathrm{pH}$ & $6.50 \pm 0.10^{\mathrm{a}}$ & $9.40 \pm 0.12^{\mathrm{b}}$ & $6-8.5$ \\
\hline Conductivity $(\mu \mathrm{S} / \mathrm{cm})$ & $420.30 \pm 1.75^{\mathrm{a}}$ & $2926.10 \pm 20.13^{\mathrm{b}}$ & $0-3$ \\
\hline Total Solids Salts (mg/L) & $425.60 \pm 2.75^{\mathrm{a}}$ & $780.20 \pm 2.15^{\mathrm{b}}$ & 2000 \\
\hline Suspended Solid (mg/L) & $110.20 \pm 2.50^{\mathrm{a}}$ & $540.15 \pm 4.30^{\mathrm{b}}$ & - \\
\hline Phosphorus (mg/L) & $0.14 \pm 0.002^{\mathrm{a}}$ & $7.30 \pm 0.20^{\mathrm{b}}$ & - \\
\hline Sodium Adsorption Ratio & $0.60 \pm 0.05^{\mathrm{a}}$ & $43.25 \pm 0.45^{\mathrm{b}}$ & 0.55 \\
\hline $\begin{array}{l}\text { Biochemical Oxygen Demand } \\
\qquad(\mathrm{mg} / \mathrm{L})\end{array}$ & $15.75 \pm 0.14^{\mathrm{a}}$ & $280.50 \pm 2.50^{\mathrm{b}}$ & 100 \\
\hline $\mathrm{N}-\mathrm{NO}_{3}^{-} \quad(\mathrm{mg} / \mathrm{L})$ & $15.25 \pm 0.17^{\mathrm{a}}$ & $160.10 \pm 1.30^{\mathrm{b}}$ & 10 \\
\hline $\mathrm{N}-\mathrm{NH}_{4}^{+} \quad(\mathrm{mg} / \mathrm{L})$ & $0.35 \pm 0.002^{\mathrm{a}}$ & $9.70 \pm 0.30^{\mathrm{b}}$ & 30 \\
\hline
\end{tabular}

Values with the different letter in the same line are significantly different at $\mathrm{P}<0.01$.

was higher than values obtained by Somda et al. [9] and FAO limits values. The conductivity of Kossodo waters was 5 times higher than those of Boulmiougou. Total solids salts and suspended solids in the prospected sites were ranged from $425.60 \pm 2.15$ to $780.20 \pm 2.15 \mathrm{mg} / \mathrm{L}$ and $110.20 \pm 2.50$ to $540.15 \pm 4.30 \mathrm{mg} / \mathrm{L}$ respectively for Boulmiougou and Kossodo. Also the phosphorus content was ranged respectively $7.30 \pm 0.20$ and $0.14 \pm 0.002 \mathrm{mg} / \mathrm{L}$. The values of biochemical oxygen demand varied from $15.75 \pm 0.14$ to $280.50 \pm 2.50 \mathrm{mg} / \mathrm{L}$.

The nitrate content of Kossodo samples $(160.10 \pm 1.30 \mathrm{mg} / \mathrm{L})$ was significantly higher $(\mathrm{P}<0.01)$ than those of Boulmiougou $(15.25 \pm 0.17 \mathrm{mg} / \mathrm{L})$. Results of ammonium content revealed a significant difference $(\mathrm{P}<0.01)$ in the same order of samples $(9.70 \pm 0.30 \mathrm{mg} / \mathrm{L}$ and $0.35 \pm 0.002 \mathrm{mg} / \mathrm{L})$. The different values of wastewater parameters of Kossodo have been ranged higher to acceptable safe limit of FAO standards [29]. These high values are due to industrial activities around the Kossodo site.

According to Balkhair and Ashraf [20] wastewater irrigation significantly affected the soil chemical properties, especially at a $0-30 \mathrm{~cm}$ soil depth, and the plant nutrients. Kiziloglu et al. [30] indicated that the application of wastewater to soil increased the yield and the $\mathrm{N}, \mathrm{P}, \mathrm{K}, \mathrm{Fe}, \mathrm{Mn}, \mathrm{Zn}, \mathrm{Cu}, \mathrm{B}$ and Mo contents of cabbage plants without causing undesirable side effects to the plant's heavy metal contents. So for Balkhair and Ashraf [20] high BOD values adversely affect the growth of the plant. The suspended solids affect the plant growth because they reduce the permeability of the soil, which, in turn, reduces the availability of oxygen for the plant roots. Also high nitrate concentration could affect vegetable crops and would be problematic when consumed by infants, possibly causing blue baby syndrome.

\subsection{Concentration of Heavy Metal Levels in Soils Irrigated with Wastewater}

The mean concentrations for each metal, over the entire span of the sampling 
sites were shown in Table 2. The analytical results showed that concentrations elements $\left(\mathrm{mg} \cdot \mathrm{kg}^{-1}\right)$ like $\mathrm{As}, \mathrm{Cr}, \mathrm{Cu}, \mathrm{Ni}$, and $\mathrm{Zn}$ were ranged with significant difference $(\mathrm{p}<0.01)$ as $20.47 \pm 0.32,13.30 \pm 1.55,233.92 \pm 15,61.10 \pm 0.57,125.49$ \pm 11.95 from samples of Boulmiougou and $4.34 \pm 0.12,27.63 \pm 0.75,303.56 \pm$ $12.25,165.23 \pm 15.75,183.03 \pm 11.75$ for Kossodo. And yet no significant difference was found for $\mathrm{Cd}, \mathrm{Hg}$, Se in the different sites. Samples of Kossodo soil contained the highest concentration of the metals $\mathrm{Cr}, \mathrm{Cu}, \mathrm{Ni}$ and $\mathrm{Zn}$ but recorded the least concentration for As. Our findings were higher to those of Adekiya et al. (2018) [31] respectively for As $\left(0.62 \mathrm{mg} \cdot \mathrm{kg}^{-1}\right), \mathrm{Cd}\left(0.09 \mathrm{mg} \cdot \mathrm{kg}^{-1}\right), \mathrm{Cr}$ $\left(0.40 \mathrm{mg} \cdot \mathrm{kg}^{-1}\right), \mathrm{Cu}\left(4.60 \mathrm{mg} \cdot \mathrm{kg}^{-1}\right), \mathrm{Ni}\left(6.20 \mathrm{mg} \cdot \mathrm{kg}^{-1}\right), \mathrm{Pb}\left(0.24 \mathrm{mg} \cdot \mathrm{kg}^{-1}\right)$ and $\mathrm{Zn}$ (5.00 $\left.\mathrm{mg} \cdot \mathrm{kg}^{-1}\right)$. The concentration of $\mathrm{Cr}, \mathrm{Cu}, \mathrm{Ni}$ in this study exceeded the FAO/WHO standard [29]. These ranges exceed the permissible limits for mineral soils in arid and Saharan regions. At high concentrations in soil, all heavy metals have also strong toxic effects on plants which results in weak growth, yield depression, disorders in plant metabolism and reduced nutrient uptake [32] [33]. Contamination of the soil by heavy metals is often a direct or indirect consequence of anthropogenic activities [34] [35]. Sources of anthropogenic metal contamination in soils include urban and industrial wastes; mining and smelting of non-ferrous metals and metallurgical industries [36]. Additionally, one of the main sources of air pollution in urban areas are traffic, industry and fossil fuel burning for heating purposes [37].

\subsection{Concentration of Heavy Metal Levels in Wastewater}

The analytical results showed that all the studied elements were detectable in wastewater. Concentration of different metals $\left(\mathrm{mg} \cdot \mathrm{kg}^{-1}\right) \mathrm{As}, \mathrm{Cr}, \mathrm{Cu}, \mathrm{Ni}, \mathrm{Zn}$ were found with significant difference $(\mathrm{p}<0.01)$ as $9.25 \pm 0.62,6.01 \pm 0.64,105.77 \pm$ $1.3,27.65 \pm 1.36,56.74 \pm 0.76$ in the samples of Boulmiougou and $1.90 \pm 0.22$, $12.15 \pm 65,133.56 \pm 1.7,72.70 \pm 0.45,80.50 \pm 6.10$ from Kossodo. The lower metal concentration was obtained with $\mathrm{Cr}(1.40 \pm 0.92)$ of wastewater samples of

Table 2. Concentrations of heavy metals in the soil, wastewater and tomato fruit.

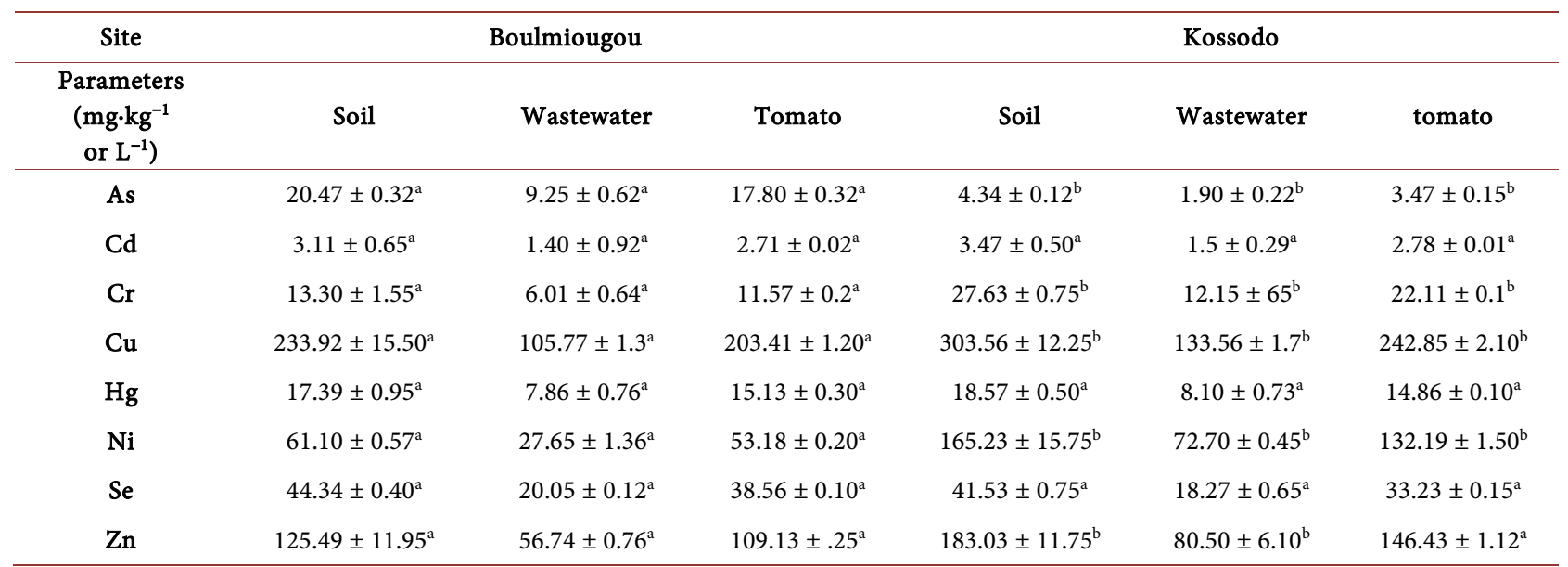

Values with the different letter in the same line are significantly different at $\mathrm{P}<0.01$. 
Boulmiougou and higher value with $\mathrm{Cu}(133.56 \pm 1.7)$ of Kossodo. Excepted As, samples of Kossodo contained highest level of $\mathrm{Cr}, \mathrm{Cu}, \mathrm{Ni}, \mathrm{Zn}$ than Boulmiougou. No significant difference $(\mathrm{p}>0.01)$ were detected concern the others elements. In contrast, Somda et al. [9] have reported a lower level of heavy metals in the wastewater from other sites as Paspanga and Tanghin. All the samples collected from the two sites were above the maximum limits in the wastewater samples set by FAO and reported by Somda et al. [9]. These findings demonstrated that high level of metals may be due to industrial activity around the sites and agricultural practices. These results may be of significant environmental consequence because it was shown that higher rates of applied water (irrigation) increased the amounts of heavy metals may lead to an accumulation in agricultural soils and plants [38].

\subsection{Concentration of Heavy Metal Levels in Tomato Irrigated with Wastewater}

The elemental analyses of all tomato fruits by were presented in Table 2. Statistical analysis showed significant difference $(\mathrm{p}<0.01)$ in concentration of As, Cr, $\mathrm{Cu}$, Ni respectively with means values $17.80 \pm 0.32,11.57 \pm 0.2,203.41 \pm 1.20$, $53.18 \pm 0.20$, for Boumioulgou and $3.47 \pm 0.15,22.11 \pm 0.1,133.56 \pm 1.7,72.70 \pm$ 0.45 for Kossodo. The load index values of heavy metals indicated that the tomatoes were strongly polluted with $\mathrm{Cu}(203.41 \pm 1.20-242.85 \pm 2.10)$ and slightly polluted with $\operatorname{Cr}(2.71 \pm 0.02-2.78 \pm 0.01)$. The means values of this study were higher comparing to reports of Adekiya et al. [31] like As (1.21), Cd (2.53), Cr (1.23), Cu (20.37), Ni (3.43) and Zn (5.37). The samples showed As, $\mathrm{Cd}, \mathrm{Cr}, \mathrm{Cu}, \mathrm{Hg}, \mathrm{Ni}, \mathrm{Se}$ and $\mathrm{Zn}$ levels that were higher than the FAO/WHO limits. The concentrations of heavy metals in tomato samples according FAO/WHO limits values in $\mathrm{mg} \cdot \mathrm{kg}^{-1}$ were of $0.1(\mathrm{As}) ; 0.1-0.2(\mathrm{Cr}), 0.1(\mathrm{~Pb}) ; 0.1$ $(\mathrm{Cu}) ; 0.1(\mathrm{Zn}) ; 0.1(\mathrm{Ni}) ; 0.02(\mathrm{Cd})$. Also these values were higher than those reports by Somda et al. (2019) [9] in different areas (Paspanga and Tanghin). The main reason of high concentration of heavy metals may due to industrial practices as the proximity of tannery factory to site of Kossodo.

These high levels of heavy metals in tomato fruit were due to wastewater level in heavy metals, agricultural methods and industrial activity around the sites. The metal concentrations showed variation which can be attributed to the differences in physiology of the different samples for uptake, exclusion, bioaccumulation and retention of heavy metals [39]. The results from earlier reports of Somda et al. [9] demonstrated that plants grown on wastewater-irrigated soils are contaminated with heavy metals and pose a health concern. According to other authors the use of wastewater from the city in agriculture irrigation may have significant effects of accumulation of toxic heavy metals in soils and agricultural practices. The use of wastewater from the city in agriculture irrigation may have significant effects of accumulation of heavy metals in soils and agricultural products [8]. These toxic heavy metals transferred and concentrated in- 
to plant tissues from the soil due to absorption that commonly occurs in the root system, where it is in direct contact with pollutants. Specially $\mathrm{Cd}$ is a non-essential heavy metal but extremely toxic even at low concentration. It causes learning disabilities and hyperactivity in children [40] [41]. At high levels, Zinc is a neurotoxin [42]. Copper is an essential substance to human life. High concentration of $\mathrm{Cu}$ may cause metal fumes fever, hair and skin discolorations, dermatitis, respiratory tract diseases, and some other fatal diseases in human beings [43]. At high concentration $\mathrm{Cr}$ is toxic and carcinogenic [44]. Exposure to nickel toxicity produces a specific form of dermatitis and may include the lining and nasal cavity cancer [45].

\subsection{Transfer Factor of Heavy Metals from Soil to Tomato Fruit}

The transfer factor (TF) values of the metals in the tomato fruit were presented in Table 3. The (TF) were not shown significant differences $(p>0.01)$ in all the sites and were exhibited mean value of 0.865 for Boulmiougou site and 0.795 for Kossodo. TF values of the metals in the samples of Boulmiougou were rather high than those of Kossodo due to $\mathrm{pH}$ of wastewater level. Wastewater of Kossodo was highly basic than dam water of Boulmiougou.

The trace metal transfer for As, Cd, Cr, Cu, Hg, Ni, Se and $\mathrm{Zn}$ concentrations in all of samples were below what are considered as acceptable limits $(<1)$ for food production in soil and vegetables. High TF values for heavy metals were shown in the soil of Boulmiougou. These results indicated that the uptake of heavy metals by food crops increase linearly with increasing metal concentrations in the soil and wastewater. This remark is in disagreement with the previous findings of Rattan et al. [46].

According to Luo et al. [47] metals that have a high transfer factor migrate to the edible part of the plant easier than do those with a low transfer factor; this is the reason that these metals reflect their high accumulation values in various food crops to such a high ratio.

\subsection{Daily Intake of Metals and Human Health Risk Assessment}

The results for the evaluation of the DIM and HRI from the heavy metal-contaminated tomato fruit were presented in Table 4 for wastewater irrigation.

The degree of toxicity of heavy metals to human being depends upon their daily intake. Heavy metals intake through consumption of tomato fruit consumed showed large variation.

The DIM of tomato fruit-sets of Boulmiougou $\left(0.0113 \mathrm{mg} \cdot \mathrm{kg}^{-1} \cdot\right.$ person- $\left.{ }^{1} \cdot \mathrm{d}^{-1}\right)$ ranged with significant difference $(\mathrm{p}<0.01)$ concern Arsenic (As) to those Kossodo $\left(0.0022 \mathrm{mg} \cdot \mathrm{kg}^{-1} \cdot\right.$ person $\left.{ }^{-1} \cdot \mathrm{d}^{-1}\right)$. The rest of elements showed no significant difference $(\mathrm{p}>0.01)$ of means values of DIM varied respectively for Cd (0.0017 0.0017), Cr (0.0073 - 0.0140), Cu (0.1294 - 0.1545), Hg (0.0094 - 0.0096), Ni (0.0338 - 0.0841), Se (0.0211 - 0.0245) and Zn (0.0694 - 0.0931). 
Table 3. Transfer factors (TF) of the heavy metals from soil to tomato fruit.

\begin{tabular}{ccc}
\hline \multirow{2}{*}{ Heavy metals $\left(\mathrm{mg} \cdot \mathrm{kg}^{-1}\right)$} & \multicolumn{2}{c}{ Site } \\
\cline { 2 - 3 } As & Boulmiougou & Kossodo \\
Cd & $0.86 \pm 0.02^{\mathrm{a}}$ & $0.79 \pm 0.01^{\mathrm{a}}$ \\
$\mathrm{Cr}$ & $0.87 \pm 0.01^{\mathrm{a}}$ & $0.80 \pm 0.02^{\mathrm{a}}$ \\
$\mathrm{Cu}$ & $0.86 \pm 0.01^{\mathrm{a}}$ & $0.80 \pm 0.02^{\mathrm{a}}$ \\
$\mathrm{Hg}$ & $0.86 \pm 0.02^{\mathrm{a}}$ & $0.80 \pm 0.02^{\mathrm{a}}$ \\
$\mathrm{Ni}$ & $0.87 \pm 0.01^{\mathrm{a}}$ & $0.80 \pm 0.01^{\mathrm{a}}$ \\
$\mathrm{Se}$ & $0.87 \pm 0.01^{\mathrm{a}}$ & $0.80 \pm 0.01^{\mathrm{a}}$ \\
$\mathrm{Zn}$ & $0.86 \pm 0.01^{\mathrm{a}}$ & $0.80 \pm 0.01^{\mathrm{a}}$ \\
\hline
\end{tabular}

Values with the different letter in the same line are significantly different at $\mathrm{P}<0.01$.

Table 4. Daily intakes of metals (DIM) $\left(\mathrm{mg} \cdot \mathrm{kg}^{-1} \cdot\right.$ person $^{-1} \cdot$ day $\left.^{-1}\right)$ and the Health Risk Index (HRI) for individual heavy metals in lettuce irrigated with wastewater.

\begin{tabular}{cccccc}
\hline & & \multicolumn{4}{c}{ Risk assessment index } \\
\cline { 3 - 6 } Heavy metals & $\begin{array}{c}\text { RfD } \\
\left(\mathrm{mg}^{-1} \mathbf{k g}^{-1} \text { day }^{-1}\right)\end{array}$ & \multicolumn{2}{c}{ Boulmiougou } & \multicolumn{2}{c}{ Kossodo } \\
\cline { 3 - 6 } & & DIM & HRI & DIM & HRI \\
\hline As & 0.5 & $0.0113^{\mathrm{a}}$ & $0.0226^{\mathrm{a}}$ & $0.0022^{\mathrm{b}}$ & $0.0044^{\mathrm{b}}$ \\
$\mathrm{Cd}$ & 0.5 & $0.0017^{\mathrm{a}}$ & $0.0034^{\mathrm{a}}$ & $0.0019^{\mathrm{a}}$ & $0.0035^{\mathrm{a}}$ \\
$\mathrm{Cr}$ & 0.3 & $0.0073^{\mathrm{a}}$ & $0.0245^{\mathrm{a}}$ & $0.0140^{\mathrm{b}}$ & $0.0469^{\mathrm{a}}$ \\
$\mathrm{Cu}$ & 0.2 & $0.1294^{\mathrm{a}}$ & $0.6472^{\mathrm{a}}$ & $0.1545^{\mathrm{a}}$ & $0.7727^{\mathrm{a}}$ \\
$\mathrm{Hg}$ & 0.14 & $0.0096^{\mathrm{a}}$ & $0.0687^{\mathrm{a}}$ & $0.0094^{\mathrm{a}}$ & $0.0675^{\mathrm{a}}$ \\
$\mathrm{Ni}$ & 0.4 & $0.0338^{\mathrm{a}}$ & $0.0846^{\mathrm{a}}$ & $0.0841^{\mathrm{a}}$ & $0.2103^{\mathrm{b}}$ \\
$\mathrm{Se}$ & 0.6 & $0.0245^{\mathrm{a}}$ & $0.0408^{\mathrm{a}}$ & $0.0211^{\mathrm{a}}$ & $0.0352^{\mathrm{a}}$ \\
$\mathrm{Zn}$ & 0.3 & $0.0694^{\mathrm{a}}$ & $0.2314^{\mathrm{a}}$ & $0.0931^{\mathrm{a}}$ & $0.3106^{\mathrm{a}}$ \\
\hline
\end{tabular}

RfD: Oral reference dose (RfD), Values with the different letter in the same line are significantly different at $\mathrm{p}<0.01$.

The HRI values were ranged for As (0.0044 - 0.0226 with significant difference, $\mathrm{p}<0.01)$, $\mathrm{Cd}(0.0017$ - 0.0035), $\mathrm{Cr}$ (0.0245 - 0.0469), $\mathrm{Cu}(0.6472-0.7727)$, $\mathrm{Hg}(0.0675-0.0687), \mathrm{Ni}(0.0846-0.2103$ with significant difference, $\mathrm{p}<0.01)$, Se $(0.0245-0.0352)$ and $\mathrm{Zn}(0.2314-0.3106)$.

The results of DIM and HRI exhibited values less than 1 . HRI $<1$, but it could not exclude a possible future human health risk via the intake of tomato fruit-sets produced in the sites of Boulmiougou and Kossodo. According to Muchuweti et al. [38], the route of exposure via the food chain is one of the key pathways of heavy metal exposure to humans.

\subsection{Microbial Quality of Tomato Fruit}

The mean bacterial count of the isolates in the food samples were expressed as $\log \mathrm{cfu} \cdot \mathrm{g}^{-1}$ and presented in Table 5. Tomato fruits were classified as acceptable 
if the bacterial count was less than or equal to $5 \mathrm{log} \mathrm{cfu} \cdot \mathrm{g}^{-1}$. Statistically, total mesophilic aerobic count exhibited with significant difference $(\mathrm{p}<0.01)$ between the samples of Boulmiougou (4.15 $\left.\pm 0.02 \mathrm{log} \mathrm{cfu} \cdot \mathrm{g}^{-1}\right)$ and Kossodo $(2.94 \pm 0.05$ $\left.\log \mathrm{cfu} \cdot \mathrm{g}^{-1}\right)$. These results were lower than $7.0 \pm 0.46 \log \mathrm{cfu} \cdot \mathrm{g}^{-1}$ reported by Adekiya et al. [31] on ready to eat tomato fruit.

A significant difference count of Enterobacteria $(\mathrm{p}<0.01)$ was found and ranged respectively $2.28 \pm 0.27$ and $1.88 \pm 0.19 \mathrm{log} \mathrm{cfu} \cdot \mathrm{g}^{-1}$. The presence of $E_{n-}$ terobacteria in raw vegetables is not necessarily associated with fecal contamination, because the majority of the genera are part of the endogenous microflora of the product [9].

The presence of bacteria concern Fecal coliform, E. coli, Salmonella spp. were detected with no significant difference from the two investigated with respectively ranged values $1.90 \pm 0.44$ to $2.01 \pm 0.19,1.20 \pm 0.11$ to $1.67 \pm 0.25,0.94 \pm$ $0.25,1.29 \pm 0.08 \mathrm{log} \mathrm{cfu} \cdot \mathrm{g}^{-1}$. According to Ray [48] did indicate that total and fecal coliforms are present in raw foods of plant origin from contaminated soil or water. Authors as Gassama et al. [49] assumed that most E. coli strains are not regarded as pathogens; however a few strains are opportunistic causing infections in immunosuppressed host.

The mean values of Staphylococcus spp., Pseudomonas spp, then yeast and moulds occurred with no significant difference $(\mathrm{p}>0.01)$ respectively $1.14 \pm$ 0.14 to $1.28 \log \mathrm{cfu} \cdot \mathrm{g}^{-1}, 0.12 \pm 0.01$ to $0.16 \pm 0.04,2.10 \pm 0.13$ to $2.90 \pm 0.35$. Studies conducted by Le Loir et al. [50] indicated that in all cases of Staphylococcal food poisoning of food, the enterotoxin producing $S$. aureus strain was exposed to temperatures suitable for the growth of $S$. aureus. Concern Pseudomonas spp, it often responsible for spoilage of fresh vegetables due to the production of pectinolytic enzymes which cause breakdown of the peptic polymers in plant cells [51]. Tournas and Katsoudas [52] referred the possible health problems associated with the presence of moulds in vegetables, as some may produce mycotoxins.

Table 5. Microbial characteristics of lettuce from Boulmiougou and Kossodo.

\begin{tabular}{ccc}
\hline Microorganismes $\left(\log \mathrm{cfu} \cdot \mathrm{g}^{-1}\right)$ & \multicolumn{2}{c}{ Tomato fruit } \\
\cline { 2 - 3 } Total mesophilic aerobic & Boulmiougou & Kossodo \\
Total coliform & $4.15 \pm 0.02^{\mathrm{a}}$ & $2.94 \pm 0.05^{\mathrm{b}}$ \\
Fecal coliform & $2.4 \pm 0.06^{\mathrm{a}}$ & $1.88 \pm 0.19^{\mathrm{a}}$ \\
E. coli & $2.01 \pm 0.19^{\mathrm{a}}$ & $1.90 \pm 0.44^{\mathrm{a}}$ \\
Salmonella spp. & $1.67 \pm 0.25^{\mathrm{a}}$ & $1.20 \pm 0.11^{\mathrm{a}}$ \\
Enterobacteria & $1.29 \pm 0.08^{\mathrm{a}}$ & $0.94 \pm 0.25^{\mathrm{a}}$ \\
Staphylococcus spp. & $2.28 \pm 0.27^{\mathrm{a}}$ & $0.40 \pm 0.15^{\mathrm{b}}$ \\
Pseudomonas spp. & $1.28 \pm 0.19^{\mathrm{a}}$ & $1.14 \pm 0.14^{\mathrm{a}}$ \\
Yeast and moulds & $0.16 \pm 0.04^{\mathrm{a}}$ & $0.12 \pm 0.01^{\mathrm{a}}$ \\
\hline
\end{tabular}

Values with the different letter in the same line are significantly different at $\mathrm{P}<0.01$. 
The counts of the different microorganisms enumerated were higher than the limits values of FAO/WHO [53]. All of samples tested in this study were presented satisfactory level of microorganisms.

\section{Conclusions}

The results of this study supply valuable information about the metal contents and microbial quality in tomato fruit irrigated with wastewater in Burkina Faso. The results showed that heavy metals are more concentrated in the samples of tomato fruits that are closer to the industrial sites.

Irrigation with wastewater exhibits an increase in the concentrations of metals in both the soil and the vegetable. Tomato, is not crops for which is suitable to be grown in industrially polluted areas, because they accumulate significant quantities of heavy metals and microorganisms can be dangerous for consumption. The present study showed significant relationship between wastewater, soil and heavy metal accumulation in vegetable. So wastewater irrigated fields can cause potential contamination with heavy metals to soil and vegetable, thus causing a threat to human beings.

\section{Acknowledgements}

The authors gratefully acknowledge the International Sciences Programme (ISP, Sweden) for his financial support.

\section{Conflict of Interest Statement}

The present study bears no conflict of interest and I on behalf of my co-author declare that there is no conflict of interest in submitting this manuscript.

\section{References}

[1] Osma, E., Ozyigit, I.I., Leblebici, Z., Demir, G. and Serin, M. (2012) Determination of Heavy Metal Concentrations in Tomato (Lycopersicon esculentum Miller) Grown in Different Station Types. Romanian Biotechnological Letters, 17, 6962-6974.

[2] Son, D., Somda, I., Legreve, A. and Schiffers, B. (2017) Phytosanitary Practices of Tomato Producers in Burkina Faso and Risks to Health and Environment. Agricultural Notebook, 26, Article No. 25005. https://doi.org/10.1051/cagri/2017010

[3] Shi, J. (2000) Lycopene in Tomatoes: Chemical and Physical Properties Affected by Food Processing. Critical Reviews in Biotechnology, 20, 293-334. https://doi.org/10.1080/07388550091144212

[4] Giovanelli, G. and Paradiso A. (2002) Stability of Dried and Intermediate Moisture Tomato Pulp during Storage. Journal of Agricultural and Food Chemistry, 50, 7277-7281. https://doi.org/10.1021/jf025595r

[5] Demirbas, A. (2010) Oil, Micronutrient and Heavy Metal Contents of Tomatoes. Food Chemistry, 118, 504-507. https://doi.org/10.1016/j.foodchem.2009.05.007

[6] Singh, A., Rajeshkumar, S., Madhoolika, A. and Fiona, M. (2010) Risk Management of Heavy Metal Toxicity through Contaminated Vegetables from Wastewater Irrigated Area of Varanasi, India. Tropical Ecology, 51, 375-387. 
http://sro.sussex.ac.uk/id/eprint/17772

[7] Naaz, S. and Pandey, S.N. (2010) Effects of Industrial Waste Water on Heavy Metal Accumulation, Growth and Biochemical Responses of Lettuce (Lactuca sativa L.). Journal of Environmental Biology, 31, 273-276.

[8] Cu, N.X. (2015) The Effects of Heavy Metals, Phosphate, Lime and Sawdust on Plant Growth and Heavy Metal Accumulation by Lettuce. ARPN Journal of Agricultural and Biological Science, 10, 241-246.

http://www.arpnjournals.com/jabs/research_papers/rp_2015/jabs_0615_736.pdf

[9] Somda, M.K., Samake, S., Kabore, D., Nikiema, M., Mogmenga, I., Dabire, Y., Ouattara, A., Keita, I., Mihin, H.B., Akakpo, Y. and Traore, A.S. (2019) Assessment of Heavy Metals and Microbial Pollution of Lettuce (Lactuca sativa) Cultivated in Two Sites (Paspanga and Tanghin) of Ouagadougou, Burkina Faso. Journal of Environmental Protection, 10, 454-471. https://doi.org/10.4236/jep.2019.103026

[10] Kachenko, A.G. and Singh, B. (2006) Heavy Metals Contamination in Vegetables Grown in Urban and Metal Smelter Contaminated Sites in Australia. Water, Air, Soil Pollution, 169, 101-123. https://doi.org/10.1007/s11270-006-2027-1 https://link.springer.com/article/10.1007/s11270-006-2027-1

[11] Arora, M., Bala, K., Shweta, R., Anchal, R., Barinder, K. and Neeraj, M. (2008). Heavy Metal Accumulation in Vegetables Irrigated with Water from Different Sources. Food Chemistry, 111, 811-815. https://doi.org/10.1016/j.foodchem.2008.04.049

[12] Bruce, J., Boschi-Pinto, C., Shibuya, K. and Black, R. (2005) WHO Estimates of the Causes of Death in Children. The Lancet, 365, 1147-1152.

https://doi.org/10.1016/S0140-6736(05)71877-8

[13] Gibbons, H.S., Kalb, S.R., Cotter, R.J. and Raetz, C.R. (2005) Role of $\mathrm{Mg}^{2+}$ and $\mathrm{pH}$ in the Modification of Salmonella Lipid A after Endocytosis by Macrophage Tumour Cells. Molecular Microbiology, 55, 425-440. https://doi.org/10.1111/j.1365-2958.2004.04409.x

[14] Alam, M.G.M., Snow, E.T. and Tanaka, A. (2003) Arsenic and Heavy Metal Contamination of Vegetables Grown in Samta Village, Bangladesh. Science of the Total Environment, 308, 83-96. https://doi.org/10.1016/S0048-9697(02)00651-4

[15] Shilev, S. and Babrikov, T. (2003) Heavy Metal Accumulation in solanaceae Plants Grown at Contaminated Area. Proceedings of the Balkan Scientific Conference of Biology, Plovdiv, Bulgaria, 19th-21st 2005, 452-460. https://web.uni-plovdiv.bg/mollov/bio/bscb2005/part1/452-460.pdf

[16] Uwah, E.I., Gimba, M.S.B. and Gwaski, P.A. (2012) Determination of Zn, Mn, Fe and $\mathrm{Cu}$ in Spinach and Lettuce Cultivated in Potiskum, Yobe State, Nigeria. Journal of Agricultural Economics and Development, 1, 69-74. http://www.academeresearchjournals.org/print.php?id=509cde8f56d25

[17] APHA (2005) Standard Methods for the Examination of Water and Wastewater. APH Association, Washington DC.

https://www.worldcat.org/title/standard-methods-for-the-examination-of-water-an d-wastewater/oclc/156744115

[18] Musa, A.I. and Parmeshwal, L. (2018) Analysis of Heavy Metals and Minerals in Fruit Juices by Inductively Coupled Plasma Mass Spectrometry Coupled with Atomic Absorption Spectroscopy. International Journal of Recent Scientific Research, 9, 25509-25511. http://dx.doi.org/10.24327/ijrsr.2018.0903.1872

[19] Li, M.H., Robinson, E.H., Oberle, D.F., Lucas, P.M. and Bosworth, B.G. (2012) Evaluation of Corn Gluten Feed and Cottonseed Meal as Partial Replacements for 
Soybean Meal and Corn in Diets for Pond-Raised Hybrid Catfish, Ictalurus punctatus $\times$ I. furcatus. Journal of the World Aquaculture Society, 43, 107-113. https://pubag.nal.usda.gov/download/55532/PDF https://doi.org/10.1111/j.1749-7345.2011.00542.x

[20] Balkhair, K.S. and Ashraf, M.A. (2016) Field Accumulation Risks of Heavy Metals in Soil and Vegetable Crop Irrigated with Sewage Water in Western Region of Saudi Arabia Saudi. Saudi Journal of Biological Sciences, 23, S32-S44.

https://doi.org/10.1016/j.sjbs.2015.09.023

[21] Chary, N.S., Kamala, C.T. and Raj, D.S.S. (2008) Assessing Risk of Heavy Metals from Consuming Food Grown on Sewage Irrigated Soils and Food Chain Transfer. Ecotoxicology and Environmental Safety, 69, 513-524.

https://doi.org/10.1016/j.ecoenv.2007.04.013

[22] United State, Environmental Protection Agency (2002) Users' Guide and Background Technical Document for USEPA Region 9'E, Preliminary Remediation Goals. https://semspub.epa.gov/work/02/103453.pdf

[23] ISO4833-1 (2013) Microbiology of the Food Chain-Horizontal Method for the Enumeration of Microorganisms. International Organization for Standardization, Geneva.

https://www.boutique.afnor.org/resources/28167a60-b20a-47a9-b620-ec8823348a5e .pdf

[24] ISO4832 (2006) Microbiology of Food and Animal Feeding Stuffs-Horizontal Method for the Enumeration of Coliforms-Colony-Count Technique. International Organization for Standardization, Geneva.

https://www.boutique.afnor.org/resources/28167a60-b20a-47a9-b620-ec8823348a5e .pdf

[25] NF ISO21528-2: V08-039 (2004) Microbiology of food-Horizontal Methods for the Detection and Enumeration of Enterobacteriaceae. Part 2: Colony Count Method. https://www.boutique.afnor.org/resources/28167a60-b20a-47a9-b620-ec8823348a5e .pdf

[26] NF EN ISO6579: V08-013 (2002) Microbiology of Food and Animal Feeding Stuffs-Horizontal Method for the Detection of Salmonella.

https://www.boutique.afnor.org/resources/28167a60-b20a-47a9-b620-ec8823348a5e .pdf

[27] ISO6888-1 (1999) Microbiology of Food and Animal Feeding Stuffs-Horizontal Method for Enumeration of Coagulase-Positive Staphylococci (Staphylococcus aureus and Other Species). International Organization for Standardization, Geneva. https://www.boutique.afnor.org/resources/28167a60-b20a-47a9-b620-ec8823348a5e pdf

[28] NFV04-504 (2006) Microbiology of Foods. Enumeration of Pseudomonas Sin Meat and Meat Products and Poultry-Routine Method.

https://www.boutique.afnor.org/resources/28167a60-b20a-47a9-b620-ec8823348a5e .pdf

[29] WHO/FAO (2007) Joint FAO/WHO Food Standard Programme. Codex Alimentarius Commission. Report of the Thirty-Eight Session of the Codex Committee on Food Hygiene, Houston, TX. http://www.fao.org/input/download/report/686/al31_13e.pdf

[30] Kiziloglu, F.M., Turan, M., Sahin, U., Angin, I., Anapali, O. and Okuroglu, M. (2007) Effects of Wastewater Irrigation on Soil and Cabbage-Plant (Brassica olerecea var. capitate cv. yalova-1) Chemical Properties. Journal of Plant Nutrition and 
Soil Science, 170, 166-172. https://doi.org/10.1002/jpln.200621971

[31] Adekiya, A.O., Oloruntoba, A.P., Ojeniyi, S.O. and Ewulo, B.S. (2018) Heavy Metal Composition of Maize and Tomato Grown on Contaminated Soils. Open Agriculture, 3, 414-426. https://doi.org/10.1515/opag-2018-0046

[32] Broos, K., Beyens, H. and Smolders, E. (2005) Survival of Rhizobia in Soil Is Sensitive to Elevated Zinc in the Absence of the Host Plant. Soil Biology and Biochemistry, 37, 573-579. https://doi.org/10.1016/j.soilbio.2004.08.018

[33] Dan, T., Hale, B., Johnson, D., Conard, B., Stiebel, B. and Veska, E. (2008) Toxicity Thresholds for Oat (Avena sativa L.) Grown in Ni-Impacted Agricultural Soils Near Port Colborne, Ontario, Canada. Canadian Journal of Soil Science, 88, 389-398. https://doi.org/10.4141/CJSS07070

[34] Gratao, P.L., Polle, A., Lea, P.J. and Azevedo, R.A. (2005) Making the Life of Heavy Metal Stressed Plants a Little Easier. Functional Plant Biology, 32, 481-494. https://doi.org/10.1071/FP05016

[35] Paiva, L.B., Oliveira, J.G., Azevedo, R.A., Ribeiro, D.R., Silva, M.G. and Vitoria, A.P. (2009) Ecophysiological Responses of Water Hyacinth Exposed to $\mathrm{Cr}^{3+}$ and $\mathrm{Cr}^{6+}$. Environmental and Experimental Botany, 65, 403-409.

[36] Suruchi and Khanna, P. (2011) Assessment of Heavy Metal Contamination in Different Vegetables Grown in and around Urban Areas. Research Journal of Environmental Toxicology, 5, 162-179. https://doi.org/10.3923/rjet.2011.162.179

[37] Demir, G., Yigit, S., Ozdemir, H., Borucu, G. and Saral, A. (2010) Elemental Concentrations of Atmospheric Aerosols and the Soil Samples on the Selected Playgrounds in Istanbul. Journal of Residuals Science and Technology, 7, 123-130.

[38] Muchuweti, M., Birkett, J.W., Chinyanga, E., Zvauya, R., Scrimshaw, M.D. and Lester, J.N. (2006) Heavy Metal Content of Vegetables Irrigated with Mixtures of Wastewater and Sewage Sludge in Zimbabwe: Implications for Human Health. Agriculture, Ecosystems \& Environment, 112, 41-48. https://doi.org/10.1016/j.agee.2005.04.028

[39] Das, A. and Das, A. (2018) Heavy Metals in Common Food Items in Kolkata, India. Euro-Mediterranean Journal for Environmental Integration, 3, 1-9. https://doi.org/10.1007/s41207-017-0039-4

[40] Hunt, J.R. (2003). Bioavailability of Iron, Zinc, and Other Trace Minerals from Vegetarian Diets. The American Journal of Clinical Nutrition, 78, 6335-6395. https://doi.org/10.1093/ajcn/78.3.633S

[41] Shah, A., Niaz, A., Ullah, N., Rehman, A., Akhlaq, M., Zakir, M. and Khan, M.S. (2013) Comparative Study of Heavy Metals in Soil and Selected Medicinal Plants. Journal of Chemistry, 2013, Article ID: 621265. https://doi.org/10.1155/2013/621265

[42] Adelekan, B.A. and Abegunde, K.D. (2011) Heavy Metals Contamination of Soil and Groundwater at Automobile Mechanic Villages in Ibadan, Nigeria. International Journal of Physical Sciences, 6, 1045-1058.

[43] Khan, S.A. Khan, L., Hussain, I., Marwat, K.B. and Akhtar, N. (2008) Profile of Heavy Metals in Selected Medicinal Plants. Pakistan Journal of Weed Sciences and Research, 14, 101-110.

https://www.academia.edu/4922473/profile_of_heavy_metals_in_selected_medicina 1_plants

[44] Duruibe, J.O., Ogwuegbe, M.O.C. and Egwurugwu, J.N. (2007) Heavy Pollution and Human Biotoxic Effects. International Journal of Physical Sciences, 2, 112-118. https://academicjournals.org/journal/IJPS/article-full-text-pdf/59CA35213127 
[45] Ezeh, H.N., Chukwu, E. (2011) Small Scale Mining and Heavy Metals Pollution of Agricultural Soils: The Case of Ishiagu Mining District, South Eastern Nigeria. Journal of Geology and Mining Research, 3, 87-104.

http://www.academicjournals.org/app/webroot/article/article1379676812_Ezeh\%20 and\%20Chukwu.pdf

[46] Rattan, R.K., Datta, S.P., Chhonkar, P.K., Suribabu, K. and Singh, A.K. (2005) Long-Term Impact of Irrigation with Sewage Effluents on Heavy Metal Content in Soils, Crops and Groundwater a Case Study. Agricultural Ecosystems and Environment, 109, 310-322. https://doi.org/10.1016/j.agee.2005.02.025

[47] Luo, C., Liu, C., Wang, Y., Liu, X., Li, F., Zhang, G. and Li, X. (2011) Heavy Metalcontamination in Soils and Vegetables Near an e-Waste Processing Site, south China. Journal Hazardous Materials, 186, 481-490. https://doi.org/10.1016/j.jhazmat.2010.11.024

[48] Ray, B. (2004) Fundamental Food Microbiology. 3rd Edition, CRC Press, Boca Raton, FL, 608 p.

http://nuristianah.lecture.ub.ac.id/files/2014/09/fundamental-food-microbiology.pdf

[49] Gassama, A, Sow, P.S., Fall, F., Camara, P., Gueye-N'diaye, A., Seng, R., Samb, B., M'Boup, S. and Aïdara-Kane, A. (2001) Ordinary and Opportunistic Enteropathogens Associated with Diarrhea in Senegalese Adults in Relation to Human Immunodeficiency Virus Serostatus. International Journal Infectious Diseases, 5, 192-198. https://doi.org/10.1016/S1201-9712(01)90069-4

[50] Le Loir, Y., Baron, F. and Gautier, M. (2003) Staphylococcus aureus and Food Poisoning. Genetique and Molecular Research, 2, 63-76.

[51] Membre, J.M. and Burlot, P.M. (1994) Effects of Temperature, $\mathrm{pH}$, and $\mathrm{NaCl}$ on Growth and Pectinolytic Activity of Pseudomonas marginalis. Applied and Environmental Microbiology, 60, 2017-2022. https://aem.asm.org/content/aem/60/6/2017.full.pdf

[52] Tournas, V.H. and Katsoudas, E. (2005) Mould and Yeast Flora in Fresh Berries, Grapes and Citrus Juices. International Journal of Food Microbiology, 105, 11-17. https://doi.org/10.1016/j.ijfoodmicro.2005.05.002

[53] FAO/WHO Codex Alimentarius Commission (2001) Food Additives and Contaminants. Joint FAO/WHO Food Standards Programme. Report of the 20th Session of the Codex Committee on Processed Fruits and Vegetables, Washington DC, 1-289. http://www.fao.org/3/a-x8723e.pdf 